Ana Dili Eğitimi Dergisi
Journal of Mother Tongue Education
ADED - JOMTE
www.anadiliegitimi.com

\title{
Türkçe Derslerinde Eleştirel Okuryazarlık
}

\author{
Önder Potur ${ }^{* *}$
}

\begin{abstract}
Özet
Eğitim hayatımızda okuryazarlık anlayışı alfabeye dayalı okuryazarlık, işlevsel okuryazarlık, eleştirel okuryazarlık ve yeni okuryazarlıklar olmak üzere bir gelişim göstermiştir. Bu okuryazarlık çeşitlerinden eleştirel okuryazarlık eğitiminin amacı sorgulayan, yeni ve alternatif fikirler üreten, adalet ve eşitlik kavramlarını önemseyen, sosyal hayata yönelik harekete geçen bireyler yetiştirmektir. Bazı ülkelerin ders müfredatlarında yer alan eleştirel okuryazarlık eğitimi yazılı ve görsel metnin sorgulanmasını ve öğrencinin daha derin düşünmesini sağlamaktadır. Eleştirel okuryazarlık eğitiminden hareketle okuma, dinleme, konuşma ve yazma becerilerini kazandırmayı amaçlayan bir öğretim sürecinin ana dili eğitimimize katkı sağlayacağı düşünülmektedir. Bu çalışmada eleştirel okuryazarlık ve ilkeleri, eğitimi, , strateji ve sorularının rehberliğinde eleştirel okuryazarlı̆ı̆ Türkçe derslerindeki yeri ve öneminin açıklanması amaçlanmıştır. Araştırmada "Eleştirel okuryazarlık nedir?", "Eleştirel okuryazarlık eğitimi nasıl yapılır?", "Eleştirel okuryazarlığın Türkçe derslerindeki yeri ve önemi nedir?" sorularına cevap aranmıştır.
\end{abstract}

Anahtar Kelimeler: Türkçe eğitimi, eleştirel pedagoji, okuryazarlık, eleştirel okuryazarlık, dil becerileri.

\section{Critical Literacy in Language Arts Education}

\begin{abstract}
Understanding of literacy in our education lives showed an improvement including alphabetbased literacy, functional literacy, critical literacy and the new literacy. The aim of critical literacy in this kind of literacy is to educate individuals questioning, generating new and alternative ideas, giving importance to the concept of justice and equality, acting for social life. In some countries, the critical literacy training curriculum provides written and visual text to be questioned and students to think more deeply. Based on the critical literacy training, it is thought that the teaching process aimed giving reading, listening, speaking and writing skills will contribute to the process of education of the language arts. In this work, it is aimed to clarify the place and importance of critical literacy in Turkish lessons with the guidance of critical literacy, the principles of critical literacy, critical literacy training, the strategy of critical literacy and its questions. In research, these questions are to be sought for: "What is critical literacy?", "How to practice critical literacy training?", "What is the place and importance of critical literacy in Turkish lessons?"
\end{abstract}

Keywords: Turkish education, critical pedagogy, literacy, critical literacy, language arts.

\footnotetext{
* Bu çalışma Çanakkale Onsekiz Mart Üniversitesi Eğitim Bilimleri Enstitüsü Türkçe Eğitimi Anabilim Dalında gerçekleştirilen “Ortaokul Türkçe Derslerinde Eleştirel Okuryazarlık Eğitimi” başlıklı doktora tezinin kuramsal çerçevesinden üretilmiştir.

${ }^{* *}$ Dr., Mehmetçik Ortaokulu, Altı Eylül, Balıkesir. onderpotur@hotmail.com
} 


\section{Giriş}

Anadili öğretimi çerçevesinde Türkçe derslerinin temel amacı öğrencilerin okuma, dinleme, konuşma ve yazma becerilerini geliştirmektir. Bu becerilerin geliştirilmesinde kullanılan uygulama, yöntem, teknik ve etkinliklerin geçerliliği, eğitim ve öğretime katkısı her zaman sorgulanmış ve bu uygulamalar geliştirilmeye çalışılmıştır. Okunan her metin, yapılan her etkinlik öğrencinin temel dil becerilerini geliştirmesi için kullanılmıştır (Güneş, 2013; Nuhoğlu, 2007; Kırkkılıç ve Akyol, 2013, Tazebay ve Çelenk, 2008;). Ancak yapılan araştırmalara ve içinde bulunduğumuz eğitim ortamına baktığımızda becerilerin kazandırılmasında bazı eksikliklerin olduğu anlaşılmaktadır. Bu eksiklikleri gidermek amacıyla farklı yaklaşım ve kuramlardan yararlanılması gerekmektedir (Güneş, 2013). Türkçe derslerinde de farklı bir kuram olarak eleştirel okuryazarlık kuramından yararlanılması uygun olacaktır.

Özgür, demokrat, eşitlik ve adalet kavramlarına değer veren bireyler yetiştirmek isteyen eleştirel okuryazarlık, eleştirel pedagojinin sınıf ortamına taşınmış halidir. Sosyal, ekonomik, kültürel ve siyasal yönleriyle birlikte bireylerin ve öğrencilerin okuma ve yazma kavramları içerisinde dönüt vermesini ve eleştirmesini içeren bir yapıdır. Eleştirel okuryazarlığa göre okuryazar olmak, sadece harfleri tanımak değil, sözcükleri ve dünyayı anlamaktır (Freire, 2003). Alanyazın taramasında ABD, Kanada ve Avustralya'da ana sınıfından üniversiteye kadar eğitim ve öğretim ortamlarında kullanılan bir okuryazarlık çeşidi olarak karşımıza çıkan eleştirel okuryazarlığın daha çok dil öğretimi dersleriyle birlikte işlendiği tespit edilmiştir (McLaughlin ve DeVoogd, 2004b). Dil sanatları sınıfında belirli ilke, yöntem, teknik ve sorular çerçevesinde yapılan eleştirel okuryazarlığın, dil öğretimi derslerine olumlu katkı yaptığı belirlenmiştir.

21. yüzyılda yaşam boyu öğrenme için eleştirel okuryazarlık becerilerinin kazandırılmasının önemli olduğunu belirtmek gerekmektedir. Günümüzde öğrenciler internet ve bilgisayar ortamında sürekli akan bilgi ve fikir deneyimi içerisindedir. Online, basılmış, elektronik oyunlar ve kitle iletişim araçları yoluyla küçük sınıflardaki çocuklar, sürekli genişleyen metin türleriyle karşılaşmaktadır. Eleştirel okuryazarlık, öğrencileri tüm yazılı, görsel, grafiksel, elektronik ve medya metinlerini inceleyip değerlendirebilmeleri için gerekli donanıma ulaştırmayı amaçlamaktadır. Öğrenciler metnin kökeni ve amacı hakkında anlamlı sorular sormayı, diğer bakış açılarını keşfetmeyi, sonuçlar üretmeyi ve gerekli eyleme geçmeyi öğrenmektedirler (Ministry of Education of Ontario, 2006). Öğrenciler; dikkatlerini nereye yönlendireceklerine, mesajları nasıl yorumlayacaklarına ve bu mesajları nasıl uygun bir şekilde kullanacaklarına karar vermek için eleştirel okuryazarlık becerilerine ihtiyaç duymaktadır.

Bu çalışmada eleştirel okuryazarlık ve ilkeleri, eğitimi, , strateji ve sorularının rehberliğinde eleştirel okuryazarlığın Türkçe derslerindeki yeri ve öneminin açıklanması amaçlanmıştır. Bu 
araştırmada "Eleştirel okuryazarlık nedir?", "Eleştirel okuryazarlık eğitimi nasıl yapılır?", "Eleştirel okuryazarlığın Türkçe derslerindeki yeri ve önemi nedir?" sorularına cevap aranmıştır. Türkçe eğitiminde yeni ve farklı bir yaklaşım olarak eleştirel okuryazarlık eğitimi ile Türkçe derslerinin ilişkilendirilmesine yönelik bu çalışmanın anadili öğretimi alan yazınına katkı sağlayacağı düşünülmektedir.

\section{Eleştirel Okuryazarlığın Tarihçesi}

Eğitimde eleştirel yaklaşımın Jean-Jacques Rousseau ile başlayıp günümüzde eleştirel pedagoglarla devam ettiği söylenebilir. Rousseau'nun etkisiyle gelişen radikal eğitim yaklaşımı bireyden başlayarak toplumsal sistemlere doğru yönelmiştir. Yani bireyin rolü toplumsal ilişkilere göre yorumlanmış ve değerlendirilmiştir (Rousseau, 2011; Yıldırım, 2011). Kısacası eğitimde radikal eleştiri ilk defa Rousseau'nun felsefi ve pedagojik görüşleriyle başlamış olup günümüzde eleştirel pedagoji ile devam etmektedir.

Eleştirel pedagojiyi oluşturan düşüncelerin pek çoğu, 20. yüzyıl boyunca Avrupa'da ortaya çıkmış olan eleştirel sosyal ve siyasi teori tarafından şekillenmiştir. Özellikle 1920 lerde kurulmuş olan ve Frankfurt Okulu olarak bilinen Frankfurt Üniversitesi'ndeki Toplumsal Araştırma Enstitüsü, eleştirel teorinin ve eleştirel pedagojinin gelişiminde önemli bir yeri olan kurum olarak bilinir. Frankfurt Okulu, kapitalist toplumda var olan eşitsizliği ve adaletsizliği eleştirmiş ve aynı zamanda yönetimlerin baskısına da karşı çıkmıştır. Kapitalist toplumların sosyal durumlarını eleştiren Frankfurt Okulu, kapitalist ekonomilere karşı yeni toplumsal eleştiri teorileri geliştirmiştir (Darder, 2009).

Tüzel (2012)'den hareketle okuryazarlık ve okuryazar kavramına yüklenen anlamları ve algıları dört başlık altında toplamak mümkündür: Alfabeye dayalı okuryazarlık, İşlevsel okuryazarlık, Eleştirel okuryazarlık, Yeni okuryazarlıklar. Okuryazarlık hareketinde birinci dönemi, alfabeye dayalı okuryazarlık olarak adlandırmak uygun olacaktır. Bu yaklaşımda okuryazarlığın alfabe temelinde tanımlanması ve okuma ve yazma eylemlerine bağlı kalınarak bir kodlama ve kod çözme becerisi olarak algılanması söz konusudur (Güneş, 2000). Okuryazarlık hareketinde ikinci dönemi ise, Güneş (2000)'in ifadesi ile işlevsel okuryazarlık olarak adlandırmak mümkündür. Bu yaklaşımda okuryazarlık, bireyleri günlük hayatın içerisinde katılımcı bireyler olmaya doğru yönlendirmede bir araç olarak görülmektedir. Eleştirel okuryazarlığı, okuryazarlık hareketinde üçüncü dönem olarak kabul edebiliriz. Paulo Freire'nin radikal eğitim hareketi doğrultusunda 1960'ların sonlarında ve 1970'ler boyunca ortaya attığı görüşleri, eleştirel okuryazarlık anlayışının temelleri olarak kabul edilebilir.

"Eleştirel pedagoji, son yirmi yıl içerisinde gelişimini hızlandırmış ve gelişen eleştirel yaklaşımın bir sonucu olarak radikal bir eğitim kuramı olarak ortaya çıkmıştır. En geniş biçimde eğitimin yeni sosyolojisi ya da eleştirel eğitim kuramı olarak tanımlanabilir." (McLaren, 2011, s. 273) Birey özgürlüğü ekseninde birey-kurum, birey-sermaye, birey-toplum, birey-eğitim ilişkileri üzerinde durmaktadır. "Eleştirel pedagoji sistematik olarak 1970'lerde başladığı için buna kaynaklık eden 
aktörler de bu dönemde ve günümüzde yaşayanlardır. Bu anlamda kaynaklık eden kişiler olarak Paulo Freire, Hanry Giroux, Stanley Aronowitz, Michael W. Apple, Maxine Grene, Doneldo Macedo ve Peter Mclaren gibi teorisyenlerdir." (Swedeen, 2011, s. 4) Fakat en önemli aktörün Paulo Freire olduğu belirtilmelidir (Yıldırım, 2011).

Eleştirel pedagojinin eğitim ortamında sınıf içerisinde uygulanması eleştirel okuryazarlığa kaynaklık etmiştir. Eleştirel teori ve eleştirel pedagoji eleştirel okuryazarlığın temel kaynaklarıdır. "Temel referanslarına bakıldığında eleştirel pedagoji, radikal demokrasinin eğitimsel değişimini ve dönüşümünü öngören bir akım olarak düşünülmelidir. Bu akımın amacı daha çok demokrasiyi sağlamak, demokrasi kültürünü zenginleştirmek ve derinleştirmek ayrıca aktif ve sürekli bir yurttaşlık bilincini kazandırmaktır." (Peters, 2005, s. 35) Yani kültürel ve sosyal politikaları izleyen, iyi okuyan ve eleştiren bir toplum oluşturmaktır.

\section{Eleştirel Okuryazarlık}

Eleştirel okuryazarlık, batı düşüncesinde ve sosyal aktivizmde zengin bir temele sahiptir fakat yine de tek bir düşünce topluluğunu temsil etmez. Sosyokültürel eleştirel okuryazarlık bakış açısı, eleştirel pedagoji ve Paulo Freire'nin düşünceleri eleştirel okuryazarlığın temelini oluşturan unsurlar olarak kabul edilebilir. Eleştirel okuryazarlık; okuryazarlığı öğretmede bir yaklaşım olduğu kadar bilginin eleştirel alııısı ve kullanıcısı olma yolunda bize ve öğrencilerimize metinle ve hayatla onu bildiğimiz ölçüde meydan okumayı sağlayan bir dizi beceri, eğilim ve stratejilerdir (McLaughlin ve DeVoogd, 2004a).

“Eleştirel okuryazarlık, eleştirel pedagoji ilkelerinin sınıf ortamında edebiyata, dil sanatlarına, yazılı ve görsel metin etkileşimlerine uygulanmasıdır. Okuryazarlık işinin sınırlarını, kelimelerin çözümlenmesi ve şifrelenmesi yoluyla işlevsel okuryazarlığa ve işlevsel okuryazarlığın ötesine taşır." (Lanltshear ve McLaren, 1993; Akt. Swedeen, 2011, s. 6) Sosyal hayata yönelik okuryazarlığın daha eleştirel ve daha fazla sorgulayıcı olması gerektiğini savunur. Bireyi; insanların tutumlarını, değerlerini, inançlarını, söyledikleri sözleri, yazılı ve görsel metinleri sorgulamaya teşvik eder.

Eleştirel okuryazarlık, dünyayı okumaları ve bir düşünce ve hareket döngüsüyle meşgul olmaları için genç öğrencilere "kelime okumayı" öğreten Paulo Freire'nin çalışmasından esinlenerek ortaya çıkarılmıştır. Buna ek olarak, yaygınlaşan yeni teknolojiler ve çeşitli okuryazarlık kuramcıları, herhangi bir metnin yalnızca bir tane ve tek doğru yorumu olduğu inancına ve metinlerin genel yorumlamalarına meydan okumuştur (Yıldırım, 2011). Metnin derinliklerinde yer alan yazarın gizli gündemlerinin okuyucu tarafından keşfedilmesi gerekmektedir.

Freire, eğitimin geleneksel bankacılık modellerini reddetmiştir. Bankacılık eğitiminde öğretmen bilgiyi öğrencilerin beynine yerleştirir ve öğrenciler bu bilgiyi alır. Bankacılık eğitimi; öğrencileri nesnelere dönüştürür, böyle bir durumda eğitim öğrencilere yapılır, öğrencilerle beraber yapılmaz (Freire, 2003). Bankacılık modellerine zıt olarak Freire, diyalog ve problem kurucu bir eğitim 
önermiştir. Freire'ye göre tüm öğrenmeler bağlantısal olduğu için, bilgi, özellikle öğrencilerin hayatlarıyla ilişkili konular hakkında öğretmen ve öğrencilerin görüşüp tartıştığında üretilir. Problemler; öğretmen veya öğrenciler tarafından kurulur ve amaçlı, yapısal bir diyalog sürecinde yanıtlar işbirliği içerisinde verilir (Peterson, 2009).

Eleştirel okuryazarlık, okuma sürecinde okuyucuları aktif katılımcı olarak görür ve sorgulamak, incelemek veya okuyucu ile yazar arasında var olan güç ilişkisine itiraz etmek için metindeki mesajı pasif bir şekilde kabul ederek ötesini düşünmeye davet eder. Güç meselelerine odaklanır ve yansımayı, derin düşünmeyi, dönüşümü ve eylemi destekler. Bu düşünme ve dönüştürmeden sonra bir hareket, bir eylem istenir (Freire, 2003). Sosyal olayların ve metinlerin içindeki gizli gündemleri ortaya çıkaran bireyin sosyal hayata yönelik harekete geçmesini ister.

Comber (2001)'e göre eleştirel okuryazarlık; okuldaki yaşamı sürdürmek, ayrıcalık ve adaletsizliği sorgulamak için dilin güçlü bir şekilde kullanılmasıdır. Luke (2004), eleştirel okuryazarlığın ikincil tahmin etmeyi, kabul görülen meyle karşı okumayı, zor ve daha zor sorular sormayı, metnin altında yatan şeyi, arkasındakini ve gerisindekini görmeyi, bu metnin kimin adına ve isteklerine göre bizim ve diğerlerinin üzerinde güç kurup kullandıklarını görmeyi ve adlandırmayı içerdiğini iddia eder.

Ciardiello (2004), eleştirel okuryazarlığı öğrenciye veya okuyucuya eleştirel bir farkındalık geliştirmesinde yardımcı olan bir dizi uygulama ve yurttaşık becerileri olarak tanımlamaktadır. Bu farkındalık, metinlerin belirli görüşleri sustururken diğerlerini öne çıkardığı şeylerdir. Eleştirel okuryazarlık illaki olumsuz bir eleştiri yapacak diye bir şey yoktur. Olumsuz bir tutuma bürünmeyi gerektirmez; daha ziyade, bir meseleye ya da konuya değişik yollardan bakabilmek ve nihayetinde değişiklik ve gelişim için olanaklar sunabilmek anlamına gelir (Vasquez, 2004). Konuya faklı açılardan bakmak okuyucunun konu hakkında farklı düşünmesini sağlayacaktır. Farklı bakış açıları, okuyucu için daha objektif ve daha demokratik bir karar için önemli bir adım olacaktır.

Freire ve Gee'nin görüşleri doğrultusunda bireylerin özgürleştirilmesi ve her türlü otorite karşısında güçlendirilmesi temelinde gelişen eleştirel okuryazarlık anlayışı, toplumsal ve siyasal olarak ayrımcılıklara ve eşitsizliklere uğramış bireylerin veya toplumların, bu durumlar hakkında bilinçlendirilmeleri, siyasal ve toplumsal olarak güçlendirilmeleri esasına dayanmaktadır. "Eleştirel okuryazarlık, anlam kurma sürecinde her türlü varsayımdan, kabulden uzak bir biçimde aktif olmayı, yorumlamayı ve yeniden üretmeyi temel alır." (Tüzel, 2012, s. 6) Bireyin dış dünya ile olan bağını derinleştirmek, geliştirmek ve değiştirmek ister.

\section{Eleştirel Okuryazarlık Eğitimi}

Eleştirel bir eğitimin amacı eleştirel bilincin geliştirilmesini sağlamaktır. Eleştirel bilinç aracılığı ile öğrenciler kelimelerin ötesine geçerek dünyayı da eleştirel okumaya ve sorgulamaya başlarlar. Eleştirel okuryazarlık öğretmen ve öğrencilerden dünyayı okumalarını ve dünyayı anlamalarını istemektedir. Eleştirel kuram ve Freire'nin görüşleri çerçevesinde eleştirel okuryazarlık adalet ve 
eşitlik kavramlarına dikkat çeker ve bunları savunur. Sosyal bir değişim için metinlere ve dünyaya eleştirel bakmak gerekir. Adaleti savunmak, eşitliği sağlamak, dünyaya ve metinlere eleştirel bakmak eleştirel okuryazarlık eğitiminin başlıca amaçlarıdır.

Bir eleştirel okuryazarlık ortamının bulunduğu sınıfta öğretmenler, genel olarak öğrencilere aşağıdaki becerileri nasıl öğrenecekleri konusunda yardımcı olacak bir sınıf ortamı oluşturlar ve geliştirirler (Shor, 1999):

- Öğrencilerin metne olan ilgilerini ve yanıtlarını belirleme

- Metinlerin ne şekilde yapılandığını belirleme ve okuyucuyu ne şekilde etkilediğini gözlemleme

- Metinlerin geçerliliği ve güvenilirliği ile birlikte metnin belirlenen önceliklerini değerlendirme

- Metinlerdeki toplumsal içerikleri düşünme ve bizim istediğimiz demokratik eğitim ve adil bir toplum bakımından ahlaki bir tutum takınma

Eleştirel okuryazarlıkta metin kavramı ve özellikleri olarak bazı düşünceler ön plana çıkmıştır (Ontario Ministry of Education, 2008):

- Tüm metinler birer yapıdır. Yazılmış olan şeyler, pek çok kararın ve belirleyici etmenlerin ürünüdür. Metinler, yapılanmış ve metinde çoktan yer edinmiş olan yazarın tutumuyla, yorumlarıyla ve sonuçlandırmalarıyla oluşan mesajlara dayanır.

- Tüm metinler çeşitli görüşler ve değerli mesajlar içerir. Yazılı, sözlü veya görsel medyadaki tüm metinler; yazarlarının veya oluşturan kişilerin görüşleri ve önyargılarını yansıtan mesajlar içerir. Bu mesajlar kasıtlı bir şekilde oluşturulmuş olabilir. Kısacası hiçbir metin tarafsız veya değersiz değildir.

- Her insan, mesajları farklı yorumlar, farklı algılar. Yaş, kültür, cinsiyet, sosyo ekonomik durum, geçmiş deneyimler ve bilgiler; bizim bir mesajı nasıl yorumladığımız konusunda önemli bir rol oynar.

- Metinler farklı ilgilere hitap ederler. Çoğu medya mesajı, çıkar elde etmek için veya ikna etmek için oluşturulmuştur. Fakat tüm metinler kasıtlı ve bilinçli olarak bir amaca yönelik oluşturulmuştur. Bu ilgiler ticari, ideolojik veya siyasi olabilir.

- Her bir basın organı, okuyucuyu ya da izleyiciyi belirli şekillerde konumlandırmak için kendilerine has dillerini oluştururlar ve geliştirirler. TV programları, web siteleri veya romanlar anlamı farklı şekilde oluşturur ve her biri ayırt edici teknikler, kurallar ve estetiklere sahiptir.

\section{Eleştirel Okuryazarlık ilkeleri}

McLaughlin ve DeVoogd (2004a), eleştirel okuryazarlık ilkelerini şu şekilde belirtmiştir:

- Yaygın olarak bilinen ve kabul gören ortak varsayımlara ve değerlere meydan okuma 
- Çok yönlü bakış açıları kullanma ve metinde yer verilmeyen veya çekinik kalmış olan şeyleri hayal etme

- Özellikle güç açısından farklııkları içeren ilişkileri inceleme

- Toplumsal adalet için harekete geçmek amacıyla okuryazarlık uygulamalarını kullanma ve yansitma

Bu aşamalara baktığımızda eleştirel okuryazarlık için temel ve vazgeçilmez ilkeler vardır. Eleştirel okuryazarlık ilk olarak meydan okumayı ve karşı koymayı düşünür. i̇kinci olarak çok taraflı düşünme ve metinde yazarın gizlediği veya önem vermediği hususları ortaya çıkarmak önemlidir. Metindeki güçlü ve güçsüzü belirlemek ve anlamak, buna göre konum almak yine eleştirel okuryazarlığın önemli bir aşamasıdır. Harekete geçmek, eylemde bulunmak, gerçek hayatta uygulamak eleştirel okuryazarlıkta ulaşılması gereken hedefler olarak kabul edilmiştir.

Eleştirel okuryazarlığın gelişimini destekleyen uygulamaların başlamasıyla öğrenciler metinlerdeki gizlenmiş gündem ve önyargıları ortaya çıkarırlar. Bu durum öğrencilerin etkileşim hâlinde olduğu toplumsal bağlam ve çevrelerin eleştirilmesine ve yeniden düzenlenmesine yol açabilir ve olası bir dönüşüm meydana getirebilir (Simpson, 1996). McLaughlin ve DeVoogd (2004a), okuyucu ve yazar arasındaki eleştirel okuryazarlığı destekleyen ilişki hakkında dört anlayış olduğunu belirtir:

- Yansımayı; dönüşümü ve eylemi destekleyen güç konularına odaklanma

- Probleme ve onun karmaşıklığına odaklanma

- Dinamik olan ve kullanıldıkları bağlamlara uyum sağlayabilen tekniklerin kullanımı

- Çoklu bakış açılarının incelemesi ve kontrolü

\section{Eleştirel Okuryazarlıkta Çoklu Bakış Açıları}

Eleştirel okuryazarlık becerilerinin bütünleyici bir açıdan öğretilmesi, öğrencilere metni çoklu bakış açılarından inceleme fırsatları tanır. Daha önce hiç bir metni sorgulamaya, yazarın bakış açısını çözümlemeye veya farklı bakış açılarını keşfetmeye teşvik edilmeyen ve öğretilmeyen öğrenciler bir metin parçasıyla karşılaştığında pasif bir duruş sergileyebilir. Simpson (1996), hikâyelerin gerçekliğin yansıması olmadığını fakat belirli bir görüş ile söyleyerek gerçekliğin seçici versiyonları olduğunu belirtir. Bu durumda dilin, görüş açısının ve diğer okuryazarlık araçlarının kullanımıyla yazar okuyucuyu bir hikâyeye belirli yollarla yanıt vermesi için konumlandırır. Metinleri birleştirerek, alternatif sonlar oluşturarak, rol alarak ve rolüne prova yaparak sınıfta eleştirel metin çözümlemesi yapılabilir. Böyle bir ders işleyişi, metne çoklu bakış açılarından bakmak için öğrencilere olanak sağlar. Öğretmen öğrencilere aşağıdaki süreçte bilgi sunarak öğrencileri bu çaba içerisine çekebilir (Adams ve Campagna, 1995; Akt. Gregory ve Cahill, 2009):

- Dâhil etme 
- Tahmin

- Çözümleme

- Yeniden yapılandırma

- Harekete geçme

Çoklu bakış açılarının ilk aşaması olan dâhil etme aşamasında öğretmen metinler vasıtasıyla sunulan durumlara farklı bakış açılarıyla bakarak öğrencileri eleştirel konuşmaya dâhil olmaları için teşvik eder. Tahmin aşamasında ise öğretmen öğrencileri metni sorgulamaya yönelik hazırlar ve çözümleme aşamasından önce öğrenciye rehberlik eder. Çözümleme aşamasında ise öğrenciler çözümlemeyle uğraşmaya başladıklarında, dâhil etme aşamasında keşfedilen metni bu kez tahmin aşamasında oluşturulan eleştirel sorularla metni yeniden ele alırlar. Bu aşamada metin üzerinde derin bir sorgulama yapılır. Yeniden yapılandırma aşaması boyunca öğrenciler bakış açılarının eşitliği veya daha önceden bastırılmış bir bakış açısına ses vermeyi destekleyen yeni bir metin oluşturmaya teşvik edilir. Eğer tartışma, öğrenciler arasında güçlü duyguları harekete geçirdiyse, metnin yazarına mektup yazma, toplum projeleri düzenleme ya da okul içerisinde alternatif etkinlikler düzenleme şeklinde harekete geçme fırsatları oluşturulur.

\section{Eleştirel Okuryazarlık Stratejileri}

Behrman (2006) ve McLaughlin ve DeVoogd (2004b), eleştirel okuryazarlık derslerinde kullanılan başlıca stratejileri şu şekilde ifade etmişlerdir:

Tamamlayı ı Metinler Okuma: Ders ortamında klasik ders kitaplarına ilave olarak öğrencileri topluma hazırlamak amacıyla internet kaynakları, televizyon programları ve reklamlar kullanılır.

Çok Yönlü Metinler Okuma: Aynı konu üzerine yazılmış farklı yazarların eserlerini okuyan öğrencinin, konu içeriğini ve yazarların farklı bakış açılarını kavraması amaçlanmaktadır.

Karşı Koyan Bir Bakış Açısı ile Okuma: Karşı koyan bir bakış açısıyla okuyan öğrencinin bir metin tarafından öne sürülen fikirler üzerine düşünebilmesi ve üstün gelen değer veya anlamı yeniden oluşturabilmesi sağlanır.

Karşıt Metinler Oluşturma: Öğrenciler okudukları bir metni yeniden değerlendirirler, zıt veya alternatif fikirler içeren yeni metinler oluştururlar.

Öğrencinin Seçmesi Için Fırsatlar Tanıma: Öğrenciler seçtikleri kitapları okurlar ve incelerler, bu inceleme esnasında yazarın hangi fikirleri ön plana aldığını tespit ederler.

Toplumsal Eylem Takınma: Öğrenciler ders ortamında elde ettikleri bilgi ve beceriyi, toplumu daha iyi tanımak ve yönlendirmek için sınıf dışına çeşitli uygulama ve faaliyetlerle taşırlar.

Medya ve Teknolojiyi Birleştirme: Medya ve teknolojiyi birleştirmek, eleştirel okuryazarlığı sınıfa dâhil etmenin bir diğer popüler yöntemidir. Internet, popüler medya ve teknoloji, her toplumda gittikçe artan daha büyük bir işleve sahiptir. Öğretmenler, öğrencilere medya ve 
teknolojinin yaşamları üzerindeki güçlü etkisini nasıl yönlendireceklerini ve nasıl sorgulayacaklarını göstermelidir.

Örnekli partner okuması: Stratejik okumaya katkı sağlayan ve bir eş ile etkileşimli okuma yapılması gereken bir eleştirel okuryazarlık tekniğidir. Ders işleyişi sürecinde öğrenciler eşleriyle küçük bir grup şeklinde okudukları metni tartışırlar.

Sayfa işareti tekniği: Öğrencilerin anlamaları, izlemeleri ve metinler hakkında ölçücü yargılar yapmaları konusunda yardımcı olan bir uygulamadır. Okumadan sonra öğrencilerin sayfa işaretlerine not almış oldukları fikirler, tartışma için bir temel olarak kullanııır.

Bağlantı çubukları: Öyküleyici veya bilgilendirici bir metni okurken bağlantılar oluşturmayı sağlayan cümle kalıplarıdır. Bağlantı kuran cümle kalıpları öğrencilere düşünmelerini gözlemleme ve okuma sürecinde yansımaya teşvik etme konusunda yardımcı olur.

Bir şeyler söyle: Öğrencilerin okuduklarını gözlemlemelerine, bağlantı kurma yoluyla yardımcı olur. Öğrencilerin seçtiği veya öğretmenin belirlediği yerlerde öğrenciler, okumuş oldukları hakkında eşlerine "bir şey söylemek" amacıyla dururlar. Eşlerine söyledikleri şeyler yeni olan bir fikir olabilir veya bir karakterin eylemlerine karşı bir yorum olabilir.

Hikâyenin geri kalanı: Öğrencileri metinde kayıp olan veya üstü kapalı olan unsuru incelemeleri ve bu bakış açısını araştırmaları için kendi geçmiş bilgilerini kullanmaya teşvik eden problem oluşturma işleminin bir uyarlanma hâlidir. Bir metnin devamı sayılabilecek veya bir metnin anlaşıımasını kolaylaştıracak yeni metinlerle okunan hikâyenin devamı ve içeriği daha iyi anlaşılacaktır.

Değiştirme

Öğrencileri, eleştirel düşünmeye teşvik etmenin bir diğer etkili şekli "Değiştirme" yoluyla yapılır. Öğrenci, okuduğu metnin bazı özellik ve unsurlarını sorgulayarak değiştirmeye çalışır. Değiştirme tekniğinin başlıca uygulama çeşitleri şunlardır:

- Cinsiyet değiştirme

- Konu değiştirme

- Yer ve zaman değiştirme

- Vücut yapısı değiştirme

- Kıyafet değiştirme

- Duygu değiştirme

- Etnik ve ırk değiştirme

- Dil değiştirme

- Illişki ve örgütlenme değiştirme 


\section{Eleştirel Okuryazarlık Soruları}

Yapılan alan yazın araştırmasında eleştirel okuryazarlık derslerinde bazı soruların ön plana çıktığı anlaşılmıştır. Öğrencilere ders işleyişinde sorulan bu sorular aracılığı ile öğrencilerin eleştirel okuryazarlık ortamına dâhil olmaları ve sorgulama sürecine katılmaları amaçlanmıştır. Bu eleştirel okuryazarlık soruları metnin amacına, yapısına, karakterlerine, boşluklarına, güç ilişkisine, görüşüne, yazarına ve farklı anlamlarına göre çeşitlenmiştir. Sınıfta eleştirel okuryazarlık ortamının oluşturulmasını sağlayan başlıca sorular şunlardır (http:// www. education. tas.gov.au/ curriculum/ standards/ english/ teachers/ critical literacy questions):

Metinsel amaçlar

- Metnin amacı ne? Bunu nereden biliyoruz?

- Bu metni okuması ve gözlemlemesi en muhtemel kimdir, niçin?

- Bu metni biz niçin okuyoruz?

- Metnin yazarının bizden bilmemizi istediği şey nedir?

Metinsel yapılar ve özellikleri

- Metnin yapısı ve özellikleri nelerdir?

- Metin hangi türe aittir?

- Resimler, imajlar neler tavsiye ediyor?

- Kelimeler neler tavsiye ediyor?

- Metinde hangi tür dil kullanılmıştır?

Karakterlerin oluşumu

- Metinde çocuklar, ergenler ve genç yetişkinler nasıl oluşturulmuş?

- Yetişkinler nasıl oluşturulmuş?

- Yazar, karakterleri niçin özel bir yöntemle sunuyor? Boşluklar

- Metinde herhangi bir boşluk var mı?

- Metinden kim çıkartılıyor? Kim eksik?

- Metinde ne eksik bırakılmıs?

- Metinden hangi sorular çıkmıyor? Güç ve ilgililer

- Metin kimin ilgisinde?

- Metinden kim yararlanıyor?

- Metin adil mi?

- Okuyucu ya da gözlemcinin metni anlaması için hangi bilgileri metne getirmesi gerekir?

- Metinde hangi yer, ses ve ilginin oyunda olması gerekir?

- Metin okuyucu ya da gözlemcinin metin yazarıyla ilişkisi nasıldır? 
- Metin yaş, cinsiyet veya kültür gruplarını nasıl resmetmiş?

- Metinde kimin fikirleri ön plandadır?

- Kimin konuşmasına izin veriliyor?

- Kimden alıntı yapılmış?

- Metin niçin bu yöntemle yazıımış? Kimin görüşü/kimin gerçeği

- Metin hangi dünya görüşünü yansıtıyor?

- Metinde ne tür sosyal meselelere yer veriliyor?

- Metin bir gerçeği nasıl oluşturuyor?

- Metindeki gerçek nedir?

- Metin farklı bir zamanda, yerde veya kültürde anlatılsaydı nasıl olurdu? Yazarı sorgulama

- Ne çeşit, hangi ilgi ve değerlere sahip bir kişi metni yazmış?

- Metnin yazarı hangi dünya görüşü ve değerlerini okuyucunun ve gözlemcinin ele alacağını düşünmüş? Bunu nasıl anlıyoruz?

Çoklu anlamlar

- Başka hangi muhtemel yorumlar yapılabilir?

- Metnin nasıl yorumlandığını diğer faktörler nasıl etkiler?

- Metin başka nasıl yorumlanabilirdi?

- Metin kendi anlamını oluşturmak için özüne nasıl bağlı kalmış?

\section{Eleştirel Okuryazarlık Eğitiminin Önemi}

Öğrencilerin anlama, yorumlama ve eleştirme becerilerini ders programlarında yer aldığı gibi kazandırmak ve geliştirmek önemlidir. Okuldan topluma yönelik yapılan faaliyetler başta olmak üzere etkin bilgi kullanımını sağlayacak okuryazarlık çalışmaları hem kuramsal hem de aktif uygulamalarla yaygınlaştırılmalıdır (Önal, 2010). Toplumun okuma, okuryazarlık türleri, öğrenme, sorun çözme, bilgi ve iletişim teknolojileri ile ilgili yetenek düzeylerini yükselten eğitim hizmetleri verilmelidir. Sosyal ve kültürel değişim süreci içerisinde okuryazarlık alanlarının toplumun edinmesi gereken bilgi ile bütünleşmesi toplumsal gelişme açısından önemli bir yere sahiptir.

Kitap, gazete, dergi, TV, internet vb. yazılı ve görsel iletişim araçları bir yandan insanların yaşamlarını kolaylaştırırken bir yandan da insanların gereksiz, yanlış, eksik bilgiye maruz kalmalarına sebep olmaktadır. Bundan dolayı insanların dışarıdan aldığı bilgiyi olduğu gibi almaması gerekir. Bilginin sorgulanması, eleştirilmesi, doğruluğunun araştırılması gerekmektedir. Bu süreçte eleştirel okuryazarlık önemli bir yere sahiptir (Özensoy, 2012). Eleştirel okuryazarlık, her zaman eleştirel algılamayı, yorumu ve okunan metnin yeniden yazılmasını gerektirmektedir. 
Günümüzde öğrenciler; internet yoluyla, kitaplar ve elektronik oyunlarla, kitle iletişim araçları vasıtasıyla sürekli bir fikir ve bilgi akışıyla karşı karşıya kalmaktadır. Daha küçük sınıflardan itibaren sürekli değişen ve gelişen bir metin çeşitliliğiyle karşılaşmaktadırlar. Dikkatlerini nereye yönelteceklerini, mesajı nasıl yorumlayacaklarını ve bilgiyi doğru bir şekilde nasıl kullanacaklarını belirlemek için becerilere gereksinim duymaktadırlar (Ontario Ministry of Education, 2006). Yazılı veya görsel olarak edinilen bu bilgiye eleştirel olarak yaklaşmak ve doğru yorumu yapabilmek için eleştirel okuryazarlık becerilerine ihtiyaç vardır.

Özellikle medya aracılığı ile dünyadaki güç odakları insanları istedikleri gibi yönlendirmekte ve yazılı, sözlü, görsel ve çoklu ortam metinlerini bunun için bir araç olarak kullanmaktadır. Eğitim süreci, bu yazılı ve görsel ortamların sağlıklı bir şekilde kullanılması açısından önemli bir yere sahiptir. Eğitim sürecinde gerçekleştirilecek eleştirel okuryazarlık uygulamaları ile öğrencinin okuduğunu, yazdığını ve gördüğünü daha fazla sorgulaması sağlanacaktır. Metinlere farkıı bakış açıları getirerek, metinlerdeki derin anlamları ortaya çıkararak yeniden bir yorum getirmenin önünü açacaklardır (Dal, 2012). Bunun neticesinde eleştirel okuryazar öğrenciler, kendi deneyimleri, değerleri ve görüşleriyle okuduklarını ve yazarın amacını değerlendirme fırsatı bulacaklardır.

Eleştirel okuryazarlığı oluşturmak, ilköğretim eğitiminden yetişkinlerin öğrenimine kadar tüm seviyelerdeki eğitimi içerir (Gregory ve Cahill, 2009). Okul öncesi, ilkokul, ortaokul ve yetişkin eğitiminde eleştirel okuryazarlık eğitimi uygulanabilmektedir. Yapılan alan yazın taramasında eleştirel okuryazarlığın küçük yaştan itibaren kazandırılabilecek becerileri içerdiği tespit edilmiştir. Eleştirel okuryazarlığın sadece yetişkinlere uygulanabileceği düşüncesi zayıflamıştır. Kanada, ABD ve Avustralya gibi ülkelerde anaokulundan üniversiteye kadar eleştirel okuryazarlık becerilerini ve kazanımlarını içeren ders müfredatları bulunmaktadır.

Eleştirel okuryazarlığın gelişimi, öğrencileri toplumsal bağlamdaki basit eşitsizlikler olan sosyo-ekonomik durum, ırk, sınıf, cinsiyet, cinsel yönelim vb. gibi güç konularını sorgulamaya teşvik eder (Cervetti, Pardales ve Damico, 2001). Eleştirel olarak okuryazar olmak, kimin bilgisinin ayrıcalıklı olduğunu ve üstün geldiğini daha iyi anlayabilmek için metinlerdeki mesajları okuyup eleştirebilme yeteneğini öğrencilerin kazanmış olması anlamına gelmektedir. Esas olarak eleştirel pedagojiyi kullanan öğretmenler, kişiliğin toplumsal oluşumunda dilin oynadığı işlevin nasıl değerlendirileceğini gösterirler. Öğrenciler eleştirel olarak okuryazar hâline geldiklerinde, devam etmekte olan gelişime, dünyadaki yerlerine ve deneyimlerine nasıl bir anlam verdiklerini inceleyebilirler, sorgulayabilirler.

Adaletsizliğe, eşitsizliğe ve özgürlük karşıtlarına yönelik dik durmak isteniyorsa, eleştirel bir bakış ve eleştirel bir tutum gereklidir. Eleştirel bir bakış; sadece kelimeleri, resimleri, eylemleri, sesleri vs. okumanızı gerektirmez, ayrıca bir metni ve amacını anlayabilmek için dünyayı okumayı da gerektirir (Freire, 2003). Burada metin, bir kâğıda basılmış olan yazııı kaynaktan daha ötesini ifade eder. Yani metin, toplumun gelenek ve kodlarını kullanarak bireylerin birbirleriyle iletişime geçtiği her 
türlü araçtır. (Robinson ve Robinson, 2003). Bu çerçevede şarkılar, romanlar, konuşmalar, filmler, resimler, fotoğraflar vb. gibi iletişimin bütün türleri metin olarak düşünülebilir (Coffey, 2008). Eleştirel okuryazarlık eğitimi, öğrencilerin bu metinleri sorgulaması, yeniden yapılandırması ve sosyal hayata yönelik harekete geçmesiyle toplumda daha aktif bireyler yetiştirmeyi amaçlamaktadır. Toplum içinde eleştiren, sorgulayan daha bilinçli aktif bireylerin yetişmesi açısından eleştirel okuryazarlık eğitiminin önemli bir yeri bulunmaktadır.

\section{Türkçe Derslerinde Eleştirel Okuryazarlığın Yeri}

Türkçe eğitiminin temel amacı anlama ve anlatma öğrenme alanları altında okuma, dinleme, konuşma ve yazma becerilerini öğrencilere kazandırmaktır. Türkçe dersinin işleniş sürecinde bu dört becerinin öğrenciye kazandırılması çerçevesinde etkinlikler ve uygulamalar yapılmaktadır (Sever, Kaya ve Aslan, 2006). Bu temel dil becerileri öğrencileri sınıf ve okul ortamından hareketle sosyal hayata hazırlayan beceriler olarak tanımlanabilir. Yazılı bir metnin okunması ve kavranması; sınıf ve toplum ortamında dinleme becerisinin kazandırılması, duygu ve düşüncelerini sözlü ve yazılı olarak ifade edebilmesi temel dil becerilerinin kazandırılmasına yönelik başlıca kazanımlardır (Öz, 2003; Yıldız, Okur, Arı ve Yılmaz 2010;). Ana dili öğretimi çerçevesinde gerçekleştirilen Türkçe dersleri bu becerilerin kazandırıması ve öğrencinin hayata yetiştirilmesi bakımından önemli bir yere sahiptir.

Türkçe derslerinde okuma, dinleme, konuşma ve yazma becerilerinin geliştirilmesine yönelik birçok çalışma yapılmış ve yapılmaya devam edilmektedir. Bu becerilerin geliştirilmesine yönelik hazırlanan yöntem, teknik, etkinlik ve uygulamalar her zaman sorgulanmış ve yenilenmeye çalışılmıştır. Ancak alan yazında yapılan taramalar ve yapılan araştırmalar incelendiğinde bu becerilerin kazandırılmasına yönelik bazı eksikliklerin bulunduğu görülmektedir (Güneş, 2013; Nuhoğlu ve Gökkaya, 2006; Tazebay ve Çelenk, 2008). Bununla birlikte Türkçe derslerinin hala geleneksel öğretim sisteminden kurtulmakta zorlandığı ve sınıf ve ders ortamındaki Türkçe derslerinin sıradanlaştığı gözlemlenmiştir. Bundan dolayı Türkçe eğitiminin yeni bir yaklaşıma ve yeni bir bakış açısına ihtiyaç duyduğu düşünülmektedir (Güneş, 2013). Bu çerçevede Türkçe derslerinde yeni bir yaklaşım olarak eleştirel okuryazarlık kuramından yararlanılmasının uygun olacağı düşünülmüştür.

Eleştirel okuryazarlıkla ilişkilendirilmiş Türkçe derslerinin ilk amaçlarından biri okuma becerilerinin geliştirilmesi olmalıdır. Eleştirel okuryazarlık yapabilmek için öğrencilerin sorgulayacakları konu hakkında okumaları ve bilgi sahibi olmaları gerekmektedir. Eğer öğrenciler düşüncelerini etkili bir şekilde geliştirmek istiyorlarsa öğrencilere yazılı ve görsel metinlerden oluşan zengin bir okuma ortamı sağlamak uygun olacaktır. Bu çerçevede romanlar özellikle toplumsal konulara eleştirel yaklaşmak açısından önemli kaynaklardır. Öğrencilerin ilgisini çekebilecek ve onları tartışma ortamına sevk edecek düşünce yazıları, gazete metinleri, siyasi yazılar eleştirel okuryazarlık için ideal okuma kaynakları arasında yer almaktadır. Kelimelerin etkili bir şekilde kullanıldığı ve 
fikirlerin güçlü bir şekilde ifade edildiği şiirler de yine eleştirel okuryazarlık derslerinde kullanılmaktadır (Karen, Lina ve Patricia 2006).

Günümüzde yaygınlaşan teknoloji ile birlikte internet ortamları, popüler kültür ürünleri, videolar, filmler, çizgi filmler, çizgi romanlar, afişler, reklamlar, fotoğraflar da görsel okuma materyalleri olarak eleştirel okuryazarlık derslerinde görsel okuryazarlığı geliştirmek amacıyla kullanılan metinler arasında yer almaktadır (Tüzel, 2010). Günümüz öğrencilerinin zamanının önemli bir kısmını geçirdikleri bu görsel metinlere yönelik eleştirel okuryazarlı̆̆ın kullanılması ve öğrencilerin eleştirel görsel okuma becerilerinin geliştirilmesi gerekmektedir. Bu görsel metinler arasındaki filmler güçlü eğitici araçlardandır. Eleştirel okuryazarlık öğretmenleri; öğrencilerin izlediği filmin unsurlarını, içeriğini ve güç odaklarını sorgulamalarını ve daha derin düşünmelerini teşvik eder (Karen ve ark., 2006). Eleştirel okuryazarlık dersleri ile görsel metnin toplumsal açıdan vermek istediği mesaj sorgulanır ve yeni fikirlerin üretilerek metnin mesajına meydan okunur.

Eleştirel okuryazarlıkla ilişkilendirilmiş Türkçe derslerinin önemli bir amacı da dinleme becerisinin geliştirilmesidir. Eleştirel okuryazarlık ortamında dinlemenin ayrı bir önemi vardır. Öğrenciler eleştirel okuryazarlık derslerinde etkili dinleyici olmayı öğrenmeli ve öğretmenler öğrencilere daha etkili bir dinleyici olmayı öğretmelidirler. Dinleme becerisinin kazandırıması aynı zamanda konuşma becerisini de etkileyeceği unutulmamalıdır. Eleştirel okuryazarlık ortamında öğrencilerin dinleme becerilerini geliştirmek için bazı uygulamalara yer verilebilir. Tartışma, seminer ve münazara gibi etkinliklerin uygulanması, kasetten dinledikleri bir metin üzerine tartışma ortamının oluşturulması, radyodan dinlediği bir metin üzerine tartışılması ve konuşmalarda geçen konu ve fikirlerin sorgulanması eleştirel okuryazarlık derslerinde kullanılan başlıca dinleme etkinlikleri arasında yer almaktadır (Karen ve ark., 2006).

Öğrencilerin eleştirel okuryazarlık becerilerini geliştirmenin yollarından biri konuşma becerisinin geliştirilmesidir. Bu konuşma becerisinin kazandırılmasına yönelik eleştirel okuryazarlık ortamında yapılacak en önemli uygulama ise sorgulamadır. Öğrencilerin metne yönelik yapacakları sorgulama ilk önce eleştirel okuryazarlık soruları ile sağlanabilir. Böyle bir sorgulama, toplumsal farkındalığı da geliştiren yüksek türden bir düşünmeye sevk eder. Öğrencilere metnin satırları arasına gizlenmiş anlamı keşfedecekleri fırsat verildiğinde sadece metni incelemekle kalmayacaklar aynı zamanda kendi dünyalarını da incelemeye sevk eden bir eleştirel düşünme ile meşgul olacaklardır (Karen ve ark., 2006; Kurnaz, 2011; Özdemir, 2008). Eleştirel okuryazarlığın geliştirilmesinin bir yöntemi olarak konuşmayı kullanmanın başka yolları da vardır. Doğaçlama yapmak, edebiyat halkaları ve sözlü tartışma grupları oluşturmak bu uygulamaların başlıcaları sayılabilir. Bu ortamlarda öğrencilerin doğru veya yanlı̧ cevap vermesinden ziyade öğrencilerin görüşlerini ifade etme konusunda serbest olması ve daha çok eleştirel düşünmeye odaklı olmalarıdır. Öğretmen, öğrencileri sorgulamaya ve konuşmaya yönelik teşvik etmelidir. 
Eleştirel okuryazarlıkla ilişkilendirilmiş Türkçe derslerindeki yazma faaliyetleri öğrencileri düşünmeye zorlamalı ve eleştirel okuryazarlık ortamında öğrencilere duygu ve düşüncelerini yazabilmeleri için fırsat verilmelidir. Eleştirel okuryazarlık derslerinde öğrencilerin konuyla alakalı seçim yapmaları, araştırmaları ve yazmaları teşvik edilmelidir. Öğrencilerin derste işlenen konu ile ilgili sosyal hayata yönelik bir yazı yazmaları desteklenmelidir. Öğrenci metne veya metnin yazarına gösterdiği bir meydan okumaya dair yazara, derneklere, siyasi kuruşlulara mektup yazabilmelidir. Öğrencilerin özellikle duygu dünyalarını ortaya çıkarmak için şiir yazma etkinlikleri düzenlenebilir. Öğrencilerin metinde yer alan karşı çıktıkları fikirlere yönelik kendi yazılarını oluşturmaya teşvik edilmesi gerekmektedir (Karen ve ark., 2006). Hikâyeler, hikâyelerin karakterleri, günlükler üzerine inceleme yaparak yaratıcı ve eleştirel yazma yöntemleri kullanılmalıdır.

Alan yazın taramasından hareketle eleştirel okuryazarlıkla ilişkilendirilen Türkçe derslerinin, öğrencilerin üretken ve aktif vatandaş hâline gelmeleri açısından önemli bir görevi yerine getireceği anlaşıımaktadır. Bunun için sıradanlaşmış ve geleneksel hâle gelmiş Türkçe derslerinin dışına çıkılarak öğrencilerin hayatlarındaki eşitsizliğin, adaletsizliğin ve güçlünün farkına varıp karşı koymaları amacıyla okuma, dinleme, konuşma ve yazma becerilerini geliştirecek eleştirel okuryazarlıkla ilişkilendirilmiş Türkçe derslerine ihtiyaç bulunmaktadır (Potur, 2014). Öğrencilerde metne ve hayata yönelik eleştirel farkındalık oluştururken okuma, dinleme, konuşma ve yazma becerilerinin geliştirilmesi uygun olacaktır.

\section{Sonuç}

Eğitim ve öğretim sistemimize baktığımızda öğrencilerin araştıran, sorgulayan, edindiği bilgi ve beceri ile kendi dünyasını ve toplumu değiştirmeye çalışan bir öğrenci modelinden çok uzak olduğumuz anlaşılmaktadır. Ana dili eğitimi çerçevesinde yapılan Türkçe dersinin beceri ve kazanımlarını incelediğimizde de eleştiri, sorgulama, daha derin düşünme kavramlarının yetersizliği görülmektedir. Daha çok geleneksel çerçevede yapılan Türkçe derslerine dahil edilecek eleştirel okuryazarlık becerilerinin Türkçe eğitimi anlayışında yeni bir ufuk açması düşünülmektedir. Toplum içinde daha eleştirel aktif bireylerin yetiştirilmesinde de eleştirel okuryazarlıkla ilişkilendirilmiş Türkçe eğitiminin faydalı olacağı beklenmektedir.

Ülkemizde halen 2006'da yenilenen programa rağmen Türkçe derslerinin geleneksel yöntemlerle öğretmen merkezli işlendiği görülmektedir. Bu ders işleyişine göre Türkçe derslerinde öğretmen metni okumakta sonra birkaç öğrenciye aynı metni okutmakta daha sonra da çalışma kitabındaki etkinlikler yapılmaktadır. Öğretmen Kılavuz kitabındaki uygulamalar dahi tam olarak gerçekleşmemektedir. Metne ilişkin öğretmenin sorduğu sorular da daha çok beceriden ziyade bilgi düzeyinde olup öğrencilerin metinden bu soruları bulup cevaplaması ile ders sona ermektedir. Böyle bir ders işleyişinde öğrenciler sorgulama, derin düşünme, yeniden oluşturma ve sosyal hayata yönelik harekete geçme becerilerinden yoksun kalmaktadır. 
Eleştirel okuryazarlık dersi, ülkemizde zorunlu veya seçmeli olarak okutulan dersler arasında bulunmamaktadır. Ülkemiz eğitim sisteminin, ders müfredatlarının ve öğrencilerin eleştirel okuryazarlık eğitimine çok uzak olduklarını söylemek yanlış olmaz. Yapılan alan yazın incelemesinden hareketle eleştirel okuryazarlık dersinin eğitim sistemimiz içerisine dâhil edilmesi gerektiği söylenebilir (Potur, 2014). Başta Türkçe dersi olmak üzere eleştirel okuryazarlı̆ı̆n diğer derslerle de ilişkilendirilmesi üzerine çalışmalar yapılabilir. Eleştirel okuryazarlık dersi kazanımlarının bir seçmeli dersten ziyade bir ders ile ilişkilendirilerek verilmesi, ilişkilendirilen derse ve eleştirel okuryazarlığa işlevsellik kazandıracaktır. Bu çerçevede eleştirel okuryazarlığın Türkçe dersi ile ilişkilendirilerek öğretim ortamına dâhil edilmesi hem ana dili eğitimine farkıı bir anlayış kazandıracak hem de eleştirel okuryazarlığın ana dili eğitimi gibi geniş bir alana sahip olan dersin içinde verilerek işlevselliği arttırılacaktır.

\section{Kaynakça}

Behrman, E. (2006). Teaching about language, power, and text: A review of classroom practices that support critical literacy. Journal of Adolescent and Adult Literacy, 49(6), 490-498.

Cervetti, G., Pardales, M. J., Damico, J.S. (2001). "A tale of differences: Comparing the traditions, perspectives, and educational goals of critical reading and critical literacy." Reading Online 4(9).

Ciardiello, A.V. (2004). Democracy's young heroes: An instructional model of critical literacy practices. Reading Teacher, 58, 138-147.

Coffey, H. (2008). Critical literacy. Retrieved May 13, 2009 from http://www.learnnc.org/lp/pages/4437style.

Comber, B. (2001). Critical literacy: Power and pleasure with language in the early years. Australian Journal of Language and Literacy, 24(3), 168-181.

Critical Literacy Questions. Internet'ten 18.03.2013'te http:// www. education. tas.gov.au/ curriculum/ standards/ english/ teachers/ critical literacy questions adresinden alınmıştır.

Dal, S. (2012). Illköğretim 5. sınıf Türkçe dersinde eleştirel okuryazarlık uygulamaları: Bir Eylem araştırması (Yayınlanmamış doktora tezi). Anadolu Üniversitesi Eğitim Bilimleri Enstitüsü, Eskişehir.

Darder, A. (2009). Critical pedagogy: An introduction. The critical pedagogy reader (21'd ed.) (1-20). New York: Routledge.

Freire, P. (2003). Ezilenlerin pedagojisi (Çev. D. Hattatoğlu, E. Özbek). İstanbul: Ayrıntı Yayınları.

Güneş, F. (2000). Okuma-yazma öğretimi ve beyin teknolojisi. Ankara: Ocak Yayınları.

Güneş, F. (2013). Türkçe öğretimi yaklaşımlar ve modeller. Ankara: Pegem Akademi.

Gregory, A. E., Cahill, M. A. (2009). Constructing critical literacy: Self-reflexive ways for curriculum and pedagogy. Critical literacy: Theories and practices,3(2),Boise Devlet Universitesi, Boise, USA.

Karen D. W., Lina S., Patricia W. (2006). Empowering adolescentst through critical literacy. Research into Practice: Middle School Journal, January, 55-59.

Kırkkılıç, A., Akyol, H. (Ed.) (2013). Illköğretimde Türkçe öğretimi. Ankara: Pegem A Kurnaz, A. (2011). Eleştirel düşünme öğretimi etkinlikleri. Konya: Eğitim Akademi. Luke, A. (2004). Foreward, in McLaughlin, M. and Devoogd, G. (2004). Critical Literacy: Enhancing Students 
Comprehension of Text. New York, Scholastic.

McLaren, P. (2011). Okullarda yaşam eleştirel pedagojiye giriş (Çev. M. Y. Eryaman, H. Arslan). Ankara: Anı Yayıncılık.

McLaughlin, M., Devoogd, G. L. (2004a) Critical literacy as comprehension: Expanding readerresponse. New York: Journal of Adolescent Adult Literacy, 48-1.

McLaughlin, M., DeVoogd,G.L.(2004b). Critical literacy enhancing students comprehensionof text. NewYork: Published by Scholastic Inc.

Ministry of Education of Ontario (2006). Literacy for learning - The report of the expert panel on literacy in grades 4 to 6. Ontario: Ministry of Education.

Ministry of Education of Ontario (2008). A guide to effective literacy instruction grades 4 to 6. Ontario: Ministry of Education.

Nuhoğlu, M. M. (2007). Türkçe öğretimi etkinlikleri. Ankara: Nobel Yayın Dağıtım.

Nuhoğlu, M. M., Gökkaya H. (2006). Türkçe öğretimi uygulamaları. Ankara: Nobel Yayın Dağıtım.

Önal, İ. (2010). Tarihsel değişim sürecinde yaşam boyu öğrenme ve okuryazarlık: Türkiye deneyimi. Bilgi Dünyası, 11(1), Ankara.

Öz, M. F. (2003). Uygulamalı Türkçe öğretimi. Ankara: Anı Yayıncılık.

Özdemir, O. (2008). Eleştirel düşünme. İstanbul: Kriter Yayınları.

Özensoy, A. U. (2012). Eleştirel okumaya göre düzenlenmiş Sosyal Bilgiler dersiyle ilgili öğrenci görüşleri. OMÜ Eğitim Fakültesi Dergisi, 31(1), 187-202.

Robinson, E., Robinson, S. (2003). What does it mean? Discourse, text, culture: A introduction. Sydney: McGrawHill.

Rousseau, J.J. (2011). Emile ya da çocuk eğitimi üzerine (Çev. M. Baştürk, Y. Kızılçim). Ankara: Kilit Yayınları.

Peters, M. (2005). Critical pedagogy and the future of critical theory. Critical theory and critical pedagogy today. (Ilan Gur-Ze'ev (Ed.), Studies in Education. University of Haifa, Israel.

Peterson, R. E. (2009). Teaching how to read the world and change it: Critical pedagogy in the intermediate grades. The critical pedagogy reader (2 ed.) (305-323). New York: Routledge.

Potur, Ö. (2014). Ortaokul Türkçe Derslerinde Eleştirel Okuryazarlık Eğitimi (Yayınlanmamış doktora tezi). Çanakkale Onsekiz Mart Üniversitesi Eğitim Bilimleri Enstitüsü, Çanakkale.

Sever, S., Kaya, Z. ve Aslan, C. (2006). Etkinliklerle Türkçe öğretimi. İstanbul: Morpa Kültür

Shor, I. (1999). What is critical literacy. Journal of Pedagogy, Pluralism \& Practice. Cambridge, Massachusetts: Lesley College.

Simpson, A. (1996). Critical questions: Whose questions? The Reading Teacher, 50, 118 - 127.

Swedeen, S. T. (2011). First steps in critical literacy. Degree of Master of Education Professiollal Development. University of Wisconsin-la Crosse.

Tazebay, A., Çelenk, S. (Ed.) (2008). Türkçe öğretimi ilke-yöntem-teknikler. Ankara: Maya Akademi.

Tüzel, S. (2010). Görsel okuryazarlık. Tübar, 27, 691-705.

Tüzel, S. (2012). illköğretim ikinci kademe Türkçe derslerinde medya okuryazarlığı eğitimi: Bir eylem araştırması 
(Yayınlanmamış doktora tezi). Çanakkale Onsekiz Mart Üniversitesi Eğitim Bilimleri Enstitüsü, Çanakkale.

Vasquez, V. (2004). Negotiating critical literacies with young children. Mahway, N.J. : Lawrence Erlbaum.

Yıldırım, A. (2011). Eleştirel pedagoji. Ankara: Anı Yayıncılık.

Yıldız, C., Okur, A., Arı, G., Yılmaz, Y. (2010). Kuramdan uygulamaya Türkçe öğretimi. Ankara: Pegem Akademi. 